\title{
A comparative study of three different isolates of white spot virus
}

\author{
E. Cesar B. Nadala Jr*, Philip C. Loh \\ Department of Microbiology, University of Hawaii, Honolulu, Hawaii 96822, USA
}

\begin{abstract}
Three separate isolates of white spot virus (WSV) purified from 3 different penaeid shrimp species from different countries were compared morphologically, biochemically, and genomically using the following techniques: negative stain electron microscopy, sodium dodecyl-sulfate polyacrylamide gel electrophoresis / western blot, and restriction fragment length polymorphism (RFLP), respectively. Under the electron microscope, the 3 isolates were indistinguishable. Their nucleoprotein cores exhibited the unique striated structure characteristic of the baculovirus-like agents associated with white spot syndrome. The dimensions of the nucleoprotein cores were also identical for all 3 isolates. SDSPAGE gels of purified virus preparations showed all 3 to be identical in the position of at least 3 of the most prominent protein bands of WSV, with approximate molecular weights of $19,23.5$, and $27.5 \mathrm{kDa}$. Western blat analyses also revealed these 3 same protein bands in identical positions for all 3 isolates. RFLP analyses of the viral genomes using Hind III and ECoR 1 enzymes revealed that although the 3 isolates were identical when cut with ECOR I, the isolate from Penaeus japonicus from China was distinguishable from the other 2 genomes ( $P$. monodon from lndonesia and $P$. setiferus from the U.S.) when cut with Hind III.
\end{abstract}

KEY WORDS: White spot virus Penaeid shrimp

The white spot syndrome affecting penaeid shrimps has been responsible for huge losses in shrimp aquaculture in many shrimp growing countries of the world. Consequently, researchers from some of these countries (Japan, Thailand, Taiwan) have isolated and partially characterized baculovirus-like agents which appear to be variants of the same virus if not completely identical (Nadala et al. 1998). These nonoccluded baculovirus-like agents have been previously called various names by the different laboratories that isolated them. The Penaeus monodon isolate in Thailand was called PmNOBII (Penaeus monodon non-occluded baculovirus) (Wongteerasupaya et al. 1995), the isolate from $P$. monodon, $P$. japonicus and

\footnotetext{
•E-mail: elpido@hawaii.edu
}

$P$. penicillatus in Taiwan was called WSBV (white spot syndrome associated baculovirus) (Lo et al. 1996), the isolate from $P$. japonicus in Japan was called PRDV (penaeid rod-shaped DNA virus) (Inouye et al. 1996), and the isolate from $P$. japonicus in China was called CBV (Chinese baculovirus) (Lu et al. 1997. Nadala et al. 1998a). To minimize confusion, we will refer to all of these isolates as white spot virus (WSV). This name recognizes the association of the virus with the white spot syndrome and at the same time avoids the issue of whether it is a baculovirus or not, which is at present still unresolved (Murphy et al. 1995).

Our laboratory had previously characterized an isolate of the white spot virus from Penaeus japonicus obtained from China (Lu et al. 1997). Subsequently, isolates were obtained from $P$. monodon from Indonesia and $P$. setiferus from the U.S. (Loh et al. 1998). In order to examine the relationships between these new isolates, and to determine whether or not they can be distinguished from each other, a comparative study was made of their morphology, structural viral proteins and viral genomes.

Materials and methods. The virus isolates came from gill and head soft tissues of infected farm-raised 5 to $10 \mathrm{~g}$ Penaeus japonicus from China, farm-raised adult 80 to $100 \mathrm{~g}$ (head only) P. monodon from Indonesia, and wild-caught 5 to $10 \mathrm{~g} P$. setiferus from South Carolina, USA. The Chinese and U.S. viral isolates were propagated in white shrimp $(50$ to $60 \mathrm{~g} P$. vannamei) before virus purification. Head soft tissue filtrates $[200 \mu \mathrm{l}$ of $4 \% \mathrm{w} / \mathrm{v}$ in TNE $(0.05 \mathrm{M}$ Tris, $0.1 \mathrm{M}$ $\mathrm{NaCl}, 1 \mathrm{mM}$ EDTA) prepared from WSV-infected shrimp were inoculated by intramuscular injection into the second abdominal segment of the shrimps. Two to four days after injection, moribund specimens were collected and stored at $-80^{\circ} \mathrm{C}$.

To purify the virus, $80 \mathrm{~g}$ of gill and/or head soft tissues were harvested from frozen infected shrimps. The tissues were suspended in TNE at $10 \% \mathrm{w} / \mathrm{v}$ and 


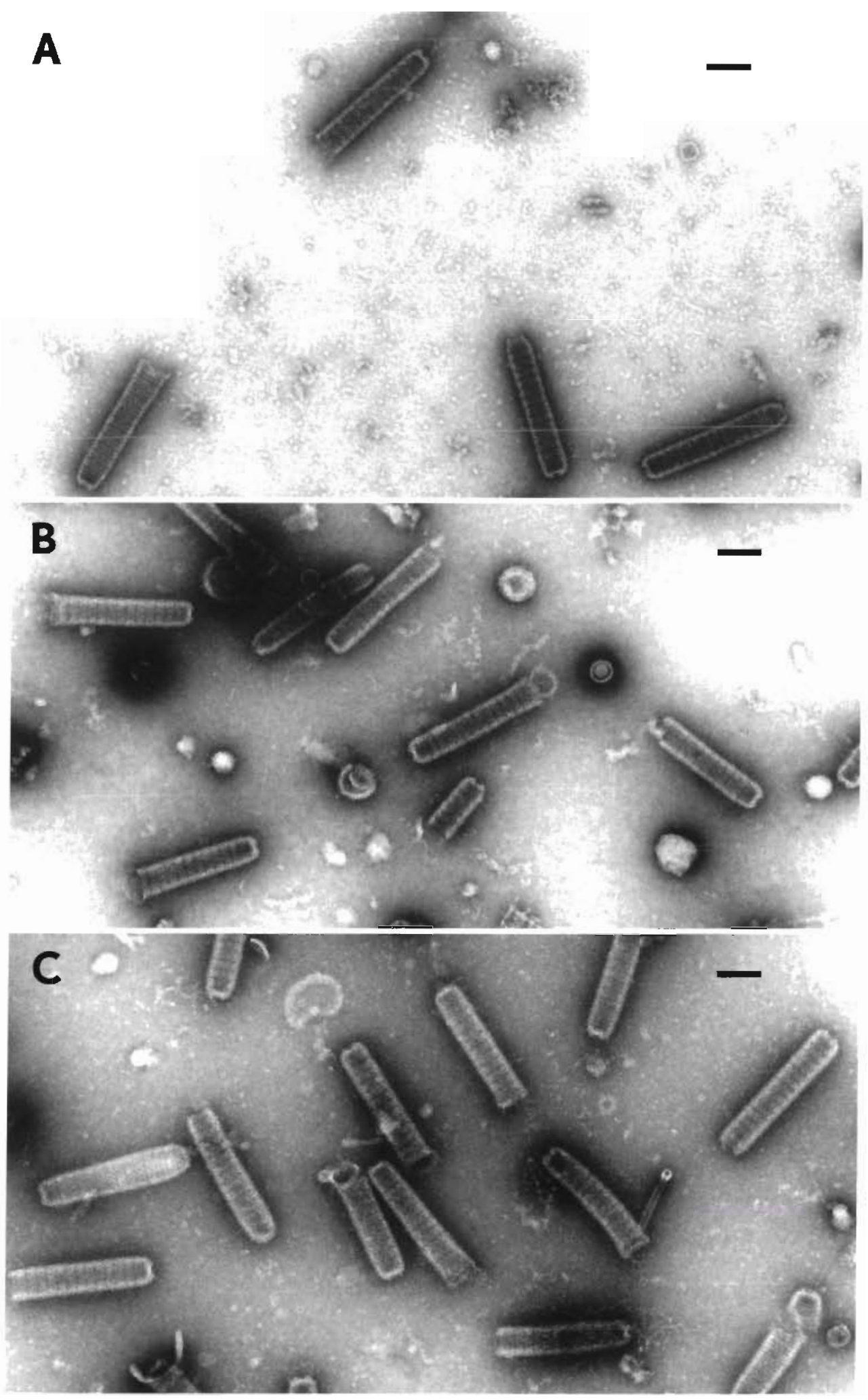

Fig. 1 Electron micrographs of negatively stained WSV particles. (A) Indonesian isolate. (B) U.S. isolate. (C) Chinese isolate. A.ll scale bars $=100 \mathrm{~nm}$ 
homogenized [Brinkmann Polytron 3000 (Kinematica AG) with 90/Polytron PT-DA 3012/2TS) (Brinkmann Instruments Inc., NY, USA). Tissue debris was pelleted twice at $4946 \times g$ for $10 \mathrm{~min}$. Virus was pelleted from the supernate at $73360 \times g$ for $20 \mathrm{~min}$, resuspended in 12:1 volume of TNE, and clarified at $2000 \times g$ for $20 \mathrm{~min}$. Virus was again pelleted from the supernate at $73360 \times g$ for $20 \mathrm{~min}$, resuspended in $2 \mathrm{ml}$ TNE, layered on top of a $30-40-50 \%$ (w/v) CsCl gradient and centrifuged at $192000 \times g$ for $19 \mathrm{~h}$ at $4^{\circ} \mathrm{C}$. The bands of virus located in the lower half of the tube were collected, diluted 1:6 in TNE, checked for purity by electron microscopy (EM), and pelleted at $73360 \times g$ for $30 \mathrm{~min}$. The pellet was resuspended in $200 \mu \mathrm{l}$ PBS and stored at $-80^{\circ} \mathrm{C}$ until needed. For EM examination, virus samples were mounted on formvar-coated, carbon-stabilized copper grids (200 mesh), negatively stained with $2 \%(\mathrm{w} / \mathrm{v})$ uranyl acetate, and examined under a Zeiss EM10/A electron microscope.

The structural proteins of the different virus isolates were analyzed by $12.5 \%$ SDS-PAGE (sodium dodecyl sulfate-polyacrylamide gel electrophoresis) according to the method of Laemmli (1970). Samples were electrophoresed for $40 \mathrm{~min}$ at $200 \mathrm{~V}$ and the gels stained using the silver stain plus kit (Biorad, CA, USA). Western blots were performed according to previously published protocols (Nadala et al. 1997).

The WSV DNA was extracted from purified virus using the QIAamp Tissue Kit (QIAGEN Inc., CA, USA). Aliquots of the DNA (100 to $300 \mathrm{ng}$ in $17 \mu \mathrm{l})$ were digested with excess Find III (10 units) or EcoR I $\left(12\right.$ units) overnight at $37^{\circ} \mathrm{C}$. Digested DNA was then subjected to electrophoresis in an agarose gel $10.7 \%$ $\mathrm{w} / \mathrm{v}$ in TBE buffer) at $30 \mathrm{~V}$ for 4 to $7 \mathrm{~h}$.
Results and discussion. Electron microscopical examination of negatively stained $\mathrm{CsCl}$-banded virus particles revealed the same conspicuous vertical striations in all 3 different isolates of WSV (Fig. 1). The dimensions of the nucleoprotein core structures were also virtually identical at 316 to $350 \mathrm{~nm}$ in length and 65 to $70 \mathrm{~nm}$ in diameter. Analysis of the structural proteins of the 3 virus isolates by SDS-PAGE gel electrophoresis of purified virus particles revealed that at least 3 of the prominent and consistent proteins of WSV $(19,23.5$, and $27.5 \mathrm{kDa})$ were in identical positions in the gel (Fig. 2A, arrowheads). Western blot analysis of the 3 virus isolates also showed these same 3 proteins to be in the same positions and with comparable staining (Fig. 2B, arrowheads). These results show that the 3 different isolates of WSV were virtually identical morphologically, by protein profile, and even antigenically by western blot.

When the purified DNA of the 3 isolates were digested with EcoR I and electrophoresed, 36 bands were distinguished. All 3 isolates showed the same pattern of bands (Fig. 3). On the other hand, when the purified DNA of each of the 3 isolates was digested with Hind III and electrophoresed, 31 bands were distinguished. When compared to each other, the isolate from China had an additional band at $15.5 \mathrm{~kb}$ (Fig. 3, arrowhead) which was missing in the other 2 isolates. The isolates from Indonesia and the U.S. had an additional band at $10 \mathrm{~kb}$ (Fig. 3, arrowhead) which was missing in the Chinese isolate. This could mean that the Indonesian and U.S. isolates are more related variants than the Chinese isolate. Our laboratory is presently doing more extensive RFLP analyses utilizing several enzymes and double digests as well as
Fig. 2. SDS-PAGE and western blot of purified WSV jsolates. (A) Silverstained gel. Lane 1. U.S.; Lane 2: Indonesia; Lane 3: China; Lane 4: Biorad low molecular weight markers (B) Western blot. Lane 1: U.S.i Lane 2: Indonesia: Lane 3: China; Lane 4: Biorad prestained broad range markers
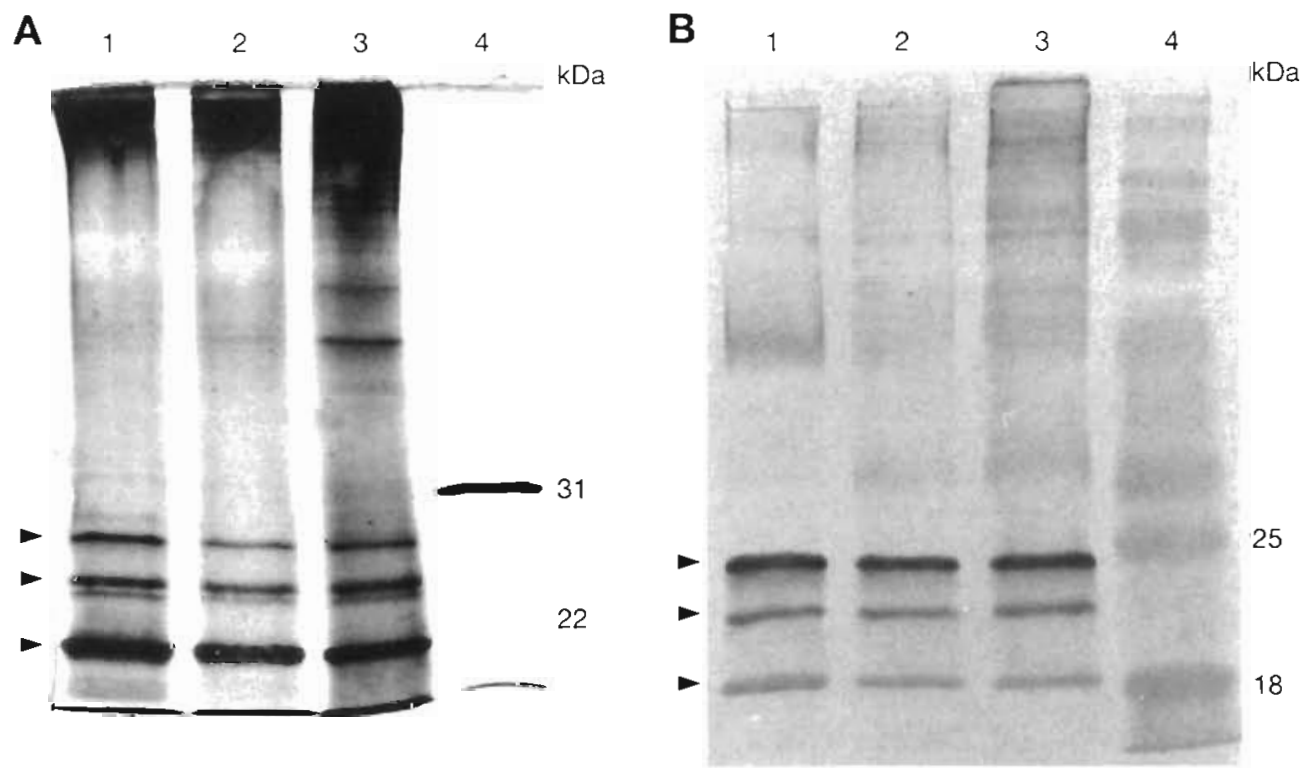


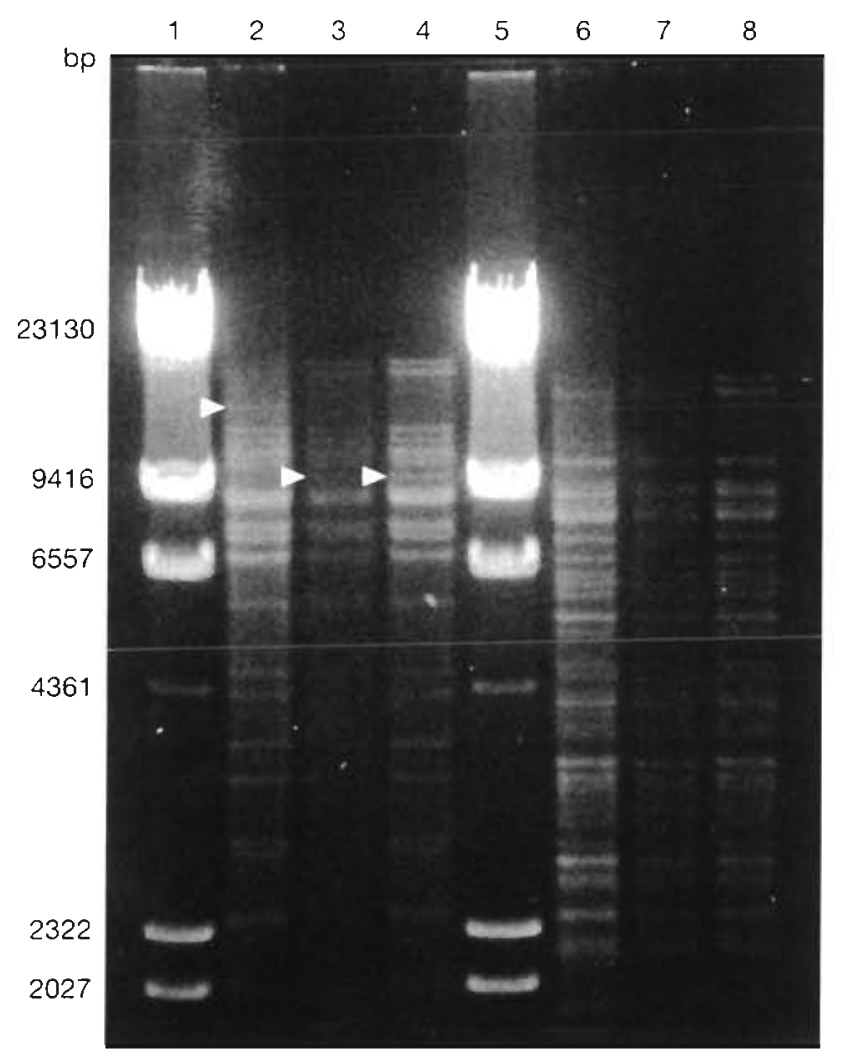

Fig. 3. Agarose gel electrophoresis of Hind III and ECoR I digested DNA from WSV isolates. Lanes 1 \& 5: Hind III digested Lambda DNA markers; Lane 2: China, Hind III digest; Lane 3: Indonesia, Hind lll digest; Lane 4: U.S., Hind III digest; Lane 6: China, EcoR I digest; Lane 7: Indonesia, EcoR I digest; Lane 8: U.S., EcoR I digest

nucleic acid sequencing to obtain a more meaningful comparison of the different isolates of WSV.

The Hind III restriction digest pattern of the WSV isolate of Wang et al. (1995) show that it is more related to the Chinese isolate than to the other 2 because of the presence of the $15.5 \mathrm{~kb}$ band, which they estimate at $16.9 \mathrm{~kb}$ in size. Despite the slight discrepancy in our size estimates, the general pattern seems to be identical with the Chinese isolate. It is not possible to compare at this time the restriction enzyme patterns of the isolates described by Wongteerasupaya et al. (1995) and Inouye et al. (1996) because Hind III digests of their isolates are not yet available.

Based on the total size of the restriction fragments, we estimate the size of the WSV genome at around 190 to $200 \mathrm{~kb}$. This figure is slightly bigger than our previously published estimate (183.9 kb) (Nadala et al. 1998) because 2 fragments ( 11.75 and $2.4 \mathrm{~kb}$ ) which migrated close to similarly sized fragments were missed in our earlier count.

The results of this study indicate that WSV can infect many different penaeid species in different areas of the world. It also supports the theory that WSV is the non-occluded baculovirus-like agent associated with white spot syndrome that has been isolated by different laboratories throughout the world. These different isolates are probably variants of WSV distinguishable only by their nucleic acid sequence. The finding of WSV in Penaeus setiferus is also worrisome as this particular penaeid species is becoming increasingly utilized in shrimp aquaculture.

Acknowledgements. This study was supported by grants from the University of Hawaii Sea Grant and College Program, Institutional Grant No. NA36RG0507, UNIHI-SEAGRANTJC-98-04, and the Aquaculture Development Program, Department of Land and Natural Resources, State of Hawaii Contract No. 38066.

\section{LITERATURE CITED}

Inouye K, Yamano $K$, Ikeda N, Kimwa T, Nakano H, Momoyama K, Kobayashi J, Miyajima S (1996) The penaeid rodshaped DNA virus (PRDV), which causes penaeid acute viremia (PAV). Fish Pathol 31:39-45

Laemmli UK (1970) Cleavage of structural protein during the assembly of the head of bacteriophage T4. Nature 227 : $680-685$

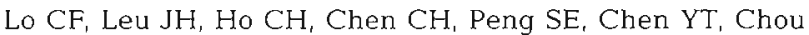
CM, Yeh PY, Huang $\mathrm{CJ}$, Chou HY, Wang $\mathrm{CH}_{1}$ Kou GH (1996) Detection of baculovirus associated with white spot syndrome (WSBV) in penaeid shrimps using polymerase chain reaction. Dis Aquat Org 25:133-141

Loh PC. Tapay LM, Nadala ECB Jr, Lu Y (1998) A SDS/ PAGE/Western blot/EIA protocol for the specific detection of shrimp viral pathogens. Proc 4th Int Mar Biotechnol (in press)

Lu Y, Tapay LM, Loh PC, Gose RB, Brock JA (1997) The pathogenicity of a baculo-like virus isolated from diseased penaeid shrimp obtained from China for cultured penaeid species in Hawaii. Aquaculture Int 5:277-282

Murphy FA, Fauquet CM, Bishop DHL, Ghabrial SA, Jarvis AW, Martelli GP, Mayo MA, Summers MD (1995) Virus taxonomy. Archives of virology. Springer Verlag, Vienna

Nadala ECB Jr, Tapay LM, Cao S, Loh PC (1997) Detection of yellowhead virus and Chinese baculovirus in penaeid shrimp by the western blot technique. J Virol Meth 69 $39-44$

Nadala ECB Jr, Tapay LM, Loh PC (1998a) Characterization of a non-occluded baculovirus-like agent pathogenic to penaeid shrimp. Dis Aquat Org 33:221-229

Wang $\mathrm{CH}$, Lo CF, Leu JH, Chou CM, Yeh PY, Chou HY, Tung MC, Chang CF, Su MS, Kou GH (1995) Purification and genomic analysis of baculovirus associated with white spot syndrome (WSBV) of Penaeus monodon. Dis Aquat Org 23:239-242

Wongteerasupaya $C$, Vickers JE, Sriurairatana S, Nash GL, Akarajamorn A, Boonsaeng V, Panyim S, Tassanakajon A, Withyachumnarnkul B, Flegel TW (1995) A nonoccluded, systemic baculovirus that occurs in cells of ectodermal and mesodermal origin and causes high mortality in the black tiger prawn Penaeus monodon. Dis Aquat Org 21:69-77 